\title{
Combined effects of resistance training and carbohydrate-restrictive or conventional diets on weight loss, blood variables and endothelium function
}

\section{Efeitos combinados do treinamento contrarresistência}

e dietas restritivas em carboidrato ou convencional

\author{
na perda de peso, variáveis sanguíneas \\ e função endotelial
}

Claudia Mello MEIRELLES ${ }^{1}$

Paulo Sergio Chagas GOMES²

\section{A B S T R A C T}

\section{Objective}

To compare the effects of either a carbohydrate-restrictive diets or a conventional hypoenergetic diet combined with resistance training.

\section{Methods}

Twenty-one overweight and obese adults participated in an eight-week program consisting of progressive resistance training combined with carbohydrate-restrictive diets (initially set at $<30 \mathrm{~g}$ carbohydrate; $\mathrm{n}=12$ ) or conventional hypoenergetic diet (30\% energetic restriction; carbohydrate/protein/lipid: $51 / 18 / 31 \%$ of total energy consumption; $\mathrm{n}=9$ ). It was hypothesized that the carbohydrate-restrictive diets would induce greater weight loss but that both diets would elicit similar effects on selected health markers. Body mass, and body composition, blood variables and flow-mediated brachial artery dilation (flow-mediated brachial artery dilation; by ultrasound) were used to assess changes due to the interventions.

\section{Results}

Significant within-group reductions in body mass $(-5.4 \pm 3.5 \% ; p=0.001$ versus $-3.7 \pm 3.0 \% ; p=0.015)$ and body fat (body fat; $-10.2 \pm 7.0 \% ; p=0.005$ versus $-9.6 \pm 8.8 \% ; p=0.017$ ) were identified for carbohydrate-restrictive

\footnotetext{
1 Escola de Educação Física do Exército, Divisão de Ensino e Pesquisa. Rio de Janeiro, RJ, Brasil.

2 Universidade do Estado do Rio de Janeiro, Instituto de Educação Física e Desportos, Laboratório Crossbridges. R. São Francisco Xavier, 524, $9^{\circ}$ andar, 20550-013, Rio de Janeiro, RJ, Brasil. Correspondência para/Correspondence to: PSC GOMES. E-mail: <gomespscg@yahoo.com.br>.

Support: PSC GOMES is supported by a Productivity Research Grant from the Conselho Nacional de Desenvolvimento Cientifico e Tecnológico (CNPq - Brasil) Process no 306115/2010-7.
} 
diets and conventional hypoenergetic diet, respectively, but there were no significant differences between groups as the result of the interventions. Fat free mass, blood variables and flow-mediated brachial artery dilation did not significantly change, except for the total cholesterol/high-density lipoprotein ratio, which was reduced $10.4 \pm 16.9 \%$ in carbohydrate-restrictive diets $(p=0.037)$ and $0.5 \pm 11.3 \%$ in conventional hypoenergetic diet $(p=0.398)$.

\section{Conclusion}

Carbohydrate-restrictive diets associated with resistance training was as effective as conventional hypoenergetic diet in decreasing body mass and body fat, as well as maintaining fat free mass, blood variables and flow-mediated brachial artery dilation, however it was more effective at lowering the total cholesterol/low density lipoprotein ratio.

Keywords: Carbohydrates. Diet. Endothelium. Nutritional status. Obesity.

\section{R E S U M O}

\section{Objetivo}

Comparar os efeitos entre a dieta com restrição de carboidratos e a dieta hipoenergética convencional combinadas com treinamento contrarresistência. Trabalhou-se com a hipótese de que as dietas com restrição em carboidratos poderiam acarretar maior perda de peso, mas que, no entanto, ambas causariam efeitos similares nos biomarcadores de saúde.

\section{Métodos}

Vinte e um adultos com sobrepeso ou obesos participaram de um programa de 8 semanas de treinamento contrarresistência progressive combinado com dieta com restrição de carboidratos (inicialmente com <30 g de carboidrato; $n=12$ ) ou com dieta hipoenergética convencional (30\% de restrição energética; carboidrato/ proteínallipídeos: $51 / 18 / 31 \%$ do valor energético total; $n=9$ ). Massa e composição corporais, variáveis sanguíneas (glicose, ureia, creatinina, ácido úrico, lipemia sanguínea, proteína c-reativa de alta sensibilidade) e dilatação fluxo-mediada da artéria braquial (por ultrassom) foram acompanhadas para observar os efeitos das intervenções.

\section{Resultados}

Foram identificadas reduções significativas na massa corporal $(-5,4 \pm 3,5 \% ; p=0,001$ versus $-3,7 \pm 3,0 \% ; p=0,015)$ e na gordura corporal $(-10,2 \pm 7,0 \% ; p=0,005$ versus $-9,6 \pm 8,8 \% ; p=0,017)$ de indivíduos em dieta com restrição de carboidratos e dieta hipoenergética convencional, respectivamente, sem diferenças significativas entre os grupos. Massa livre de gordura, variáveis sanguíneas e dilatação fluxo-mediada da artéria braquial não sofreram modificações significativas, exceto a razão colesterol totalllipoproteína de alta densidade, que reduziu $10,4 \pm 16,9 \%$ em dietas com restrição de carboidratos $(p=0,037)$ e $0,5 \pm 11,3 \%$ em dieta hipoenergética convencional $(p=0,398)$.

\section{Conclusão}

A dieta com restrição de carboidratos associada ao treinamento contrarresistência foi tão efetiva quanto a dieta convencional em reduzir a massa e a gordura corporais, assim como em manter os valores da massa livre de gordura, das variáveis sanguíneas e da dilatação fluxo-mediada da artéria braquial. No entanto, foi mais efetiva na redução da razão colesterol totalllipoproteína de baixa densidade.

Palavras-chave: Carboidratos. Dieta. Endotélio. Estado nutricional. Obesidade.

\section{INTRODUCTION}

Traditionally, Conventional diets (hypoenergetic and hypolipidic) have been recommended to promote losses in body mass and fat $^{1}$. However, interest in the effect of restricting dietary carbohydrates on body mass is increasing in the academic community. A
Carbohydrate-Restrictive Diet (CRD) is defined as a carbohydrate intake of less than $150 \mathrm{~g}$ daily ${ }^{2}$.

According to a meta-analysis that included 13 randomized and controlled trials conducted for six or twelve months ${ }^{3}$, a carbohydrate-restrictive diets accompanied by a reduction in energy intake 
led to greater losses in body mass and lowered triacylglycerol levels as well as increases in High Density Lipoprotein-cholesterol (HDL-c) compared to the conventional diet. However, the overall effect on the blood lipid profile warrants further attention because significant elevations in total and Low Density Lipoprotein-cholesterol $(L D L-c)$ were observed at the end of both six and twelve months of CRD.

Evidence for the coronary risks attributed to $C R D$ as evaluated by endothelium function is scarce and controversial. Endothelium function can be accurately assessed by Flow-Mediated Brachial Artery Dilation (FMD), which is highly sensitive for identifying coronary artery disease ${ }^{4}$. Very few studies have examined the effects of CRD on FMD. Some of them have observed significant reductions after very short intervention periods ${ }^{5,6}$, while others observed no significant changes after short- or long-term adherence to a $\mathrm{CRD}^{7,8}$.

High-sensitivity C-reactive protein, an acute-phase plasma protein, is an inflammatory biomarker strongly associated with coronary artery disease ${ }^{9}$. Studies investigating the effects of CRD on this marker have reported controversial results showing either no changes ${ }^{7}$ or decreases in this marker ${ }^{8,10}$.

There is a lack of knowledge about the influence of exercise on the overall metabolic response to hypoenergetic diets containing different contents of carbohydrate because most of the previous studies conducted with CRD were performed in sedentary individuals. In addition, resistance training has been recognized as useful in reducing health risks during periods of energy restriction ${ }^{11}$. However, the combined effects of $\mathrm{CRD}$ and resistance training on markers of health remain to be determined.

The aim of the present study was to compare the effects of CRD and conventional diet hypoenergetic diets in combination with progressive resistance training on body mass loss, body composition, blood lipids, high-sensitivity C-reactive protein and FMD. It was hypothesized that a CRD would induce greater weight loss, but that both diets would elicit similar effects on the selected health markers.

\section{METHODS}

Apparently healthy subjects were selected in response to announcements on four fitness clubs in the city of Rio de Janeiro, Brazil. A total of 38 were eligible for testing, and 32 met study inclusion/exclusion criteria. Seventeen subjects were assigned to the CRD and 15 to the conventional hypoenergetic diet group. In the CRD, twelve (71\%) completed the eight weeks program ( $32 \pm 10$ years; $1.69 \pm 0.09 \mathrm{~m}$; 8 women), and in the conventional diet group, nine $(60 \%)$ completed the study $(45 \pm 10$ years; $1.69 \pm 0.13 ; 5$ women). All subjects expressed the desire to lose body mass and had previously been enrolled in a resistance training program for at least three months, as well as in aerobic physical activities. Exclusion criteria included upper or lower limb injury, current pregnancy, diabetes, Body Mass Index (BMI) lower than $25 \mathrm{~kg} \cdot \mathrm{m}^{-2}$, use of ergogenics, stimulants or drugs, and a history of dyslipidemia or arterial hypertension within the previous six months. For participants who were subjected to the $C R D$, additional exclusion criteria were as follows: urea $>50 \mathrm{mg} \cdot \mathrm{dL}^{-1}$, creatinine $>1.5 \mathrm{mg} \cdot \mathrm{dL}^{-1}$ and uric acid $>7 \mathrm{mg} \cdot \mathrm{dL}^{-1}$ in men or $>5.7 \mathrm{mg} \cdot \mathrm{dL}^{-1}$ in women.

Subjects were permitted to choose the diet, considering dietary habits and food preferences.

All volunteers provided written informed consent. The study was approved by the Universidade Antonio Carlos Institutional Ethical Review Board (\#097/06), and was registered at the Clinical Trials registration site under NCT01096836.

Prior to the beginning of the study, all subjects completed a self-report dietary and physical activity history questionnaire. They also underwent initial body composition assessment, blood sampling and flow-mediated brachial artery 
dilation measurements. Thereafter they underwent strength tests to determine total strength (the sum of the total load multiplied by total repetitions performed during tests consisting of 8-10 maximum repetitions for three exercises, i.e., leg press, triceps pushdown, and biceps pulldown).

The intervention consisted of eight weeks of diet and progressive resistance exercise training ( 2 sets of 10 repetitions of 11 exercises for lower and upper body muscle groups with 2 minutes intervals between sets performed 3 times per week). Subjects were permitted to choose the dietary intervention based on their dietary habits and food preferences. All volunteers met with a nutritionist weekly for the first four weeks and every two weeks after the first month. At these meetings, the subjects underwent nutritional counseling and body mass measurement with subjects wearing light clothing and without shoes. To ensure adherence to the diet, they completed a 24-hour food recall at each meeting.

At the end of the training program, all laboratory and ultrasound tests were repeated. Body composition assessments and strength tests were also repeated after the first four weeks.

Subjects in the carbohydrate-restrictive diets group received handouts listing the amounts of carbohydrate in frequently consumed foods, and they were instructed to reduce carbohydrate intake to less than $30 \mathrm{~g}$ per day during the initial four weeks and to add $10 \mathrm{~g}$ of carbohydrate each week thereafter until the end of the study.

The conventional diet was designed to provide approximately $70 \%$ of each individual's energy requirements ${ }^{12}$ with $55 \%$ of the energy from carbohydrates, 15\% from proteins, and 30\% from fats, according to the recommendations of the Institute of Medicine $(I O M)^{13}$. The diet consisted of a structured plan based on the nutritional habits of each subject. Dietary data were analyzed using the software Avanutri (Avanutri Informática, Rio de Janeiro, Brazil).

Body mass, height, waist girth and skinfolds were always measured by the same experienced evaluator. Body density was estimated using the Jackson \& Pollock ${ }^{14}$ and Jackson et al. ${ }^{15}$ equations for men and women, respectively. Siri's equation ${ }^{16}$ was used to predict the percentage of body fat.

Fasting blood samples were taken and analyzed for glucose, triacylglycerol, total cholesterol, HDL-c urea, creatinine, uric acid, Alanine Aminotransferase (ALT), and high-sensitivity C-reactive protein. LDL-C was determined by the Friedewald's equation ${ }^{17}$.

All blood analyses were performed using a Roche/Hitachi 917 system (Hoffmann-La Roche AG., Switzerland) and standard kits. The inter-day coefficients of variation for each analysis were $1.8 \%$ for glucose and triacylglycerol, $1.7 \%$ for total cholesterol, 1.3\% for high-density lipoprotein, $2.3 \%$ for urea and creatinine, $1.7 \%$ for uric acid, $4.4 \%$ for ALT, and $3.0 \%$ for high-sensitivity C-reactive protein.

Flow-mediated brachial artery dilation was performed using a two-dimensional color spectral Doppler ultrasound equipped with a $14-\mathrm{MHz}$ linear transducer (Toshiba Nemio, Japan). Measures were obtained with subject in supine position. The transducer was placed on the anteromedial face of the right arm perpendicular to the centerline of the $\mathrm{arm}, 5-10 \mathrm{~cm}$ above the antecubital fossa and over the artery. Basal and post-occlusion diameters were measured between the intima-lumen interfaces at the end of diastole. The occlusion was maintained for 5 minutes using a cuff on the arm to apply pressure slightly above the systolic artery pressure, which was confirmed by the lack of a pulse on the Doppler screen. The post-occlusion was measured at the same site 60s after the blood flow was released.

The day-to-day intra-class correlation coefficient (R) and the absolute Typical Error of Measure (TEM) were $R=0.948$ and TEM $=0.05 \mathrm{~mm}$ for basal, $R=0.948$ and $T E M=0.07 \mathrm{~mm}$ for post occlusion, and $\mathrm{R}=0.842$ and $\mathrm{TEM}=2.7 \%$ for flow-mediated brachial artery dilation, as reported in a previous study ${ }^{18}$. 
The Shapiro-Wilk test showed that the data were not normally distributed. A Wilcoxon and Mann-Whitney tests were used to identify within-group and between-group differences, respectively. When multiple comparisons within a subject were necessary (for body mass, body composition, dietary and strength variables), a Bonferroni adjustment was applied; i.e., the $p$-value was divided by the number of comparisons (0.05/2: $p<0.025)$. For all other analyses, the

Table 1. Changes in the dietary composition of subjects on a Carbohydrate-Restrictive Diet or a Conventional Diet enrolled in an eight-week resistance training program. Rio de Janeiro (RJ), Brazil, 2008.

\begin{tabular}{|c|c|c|c|c|c|c|c|c|}
\hline \multirow{2}{*}{ Variables } & \multicolumn{2}{|c|}{ Baseline } & \multicolumn{2}{|c|}{ Week 1} & \multicolumn{2}{|c|}{ Week 5} & \multicolumn{2}{|c|}{ Week 8} \\
\hline & $M$ & SD & M & SD & M & SD & $M$ & SD \\
\hline \multicolumn{9}{|c|}{ Energy (MJ) } \\
\hline CRD & 10.4 & 2.4 & 5.8 & 2.4 & 6.2 & 2.0 & 5.2 & $2.0^{*}$ \\
\hline CONV & 8.8 & 2.0 & 6.2 & 1.0 & 6.4 & 1.7 & 6.0 & $2.0^{*}$ \\
\hline \multicolumn{9}{|c|}{ Protein (g) } \\
\hline CRD & 118.0 & 52.0 & 106 & 60.0 & 123.0 & 57.0 & 96.0 & 49.0 \\
\hline CONV & 114.0 & 59.0 & 141 & 130.0 & 110.0 & 58.0 & 95.0 & 48.0 \\
\hline \multicolumn{9}{|c|}{ Protein $\left(g \cdot k g^{-1}\right)$} \\
\hline CRD & 1.8 & 0.6 & 1.7 & 1.0 & 1.9 & 0.9 & 1.5 & 0.8 \\
\hline CONV & 2.0 & 1.2 & 2.5 & 2.5 & 1.9 & 1.1 & 1.6 & 0.7 \\
\hline \multicolumn{9}{|c|}{ Protein (\%) } \\
\hline CRD & 18.0 & 5.0 & 29 & 11.0 & 32.0 & 7.0 & 30.0 & $6.0^{*}$ \\
\hline CONV & 22.0 & 9.0 & 22 & 11.0 & 28.0 & 10.0 & 26.0 & 6.0 \\
\hline \multicolumn{9}{|c|}{ Carbohydrate (g) } \\
\hline CRD & 302.0 & 42.0 & 97 & 53.0 & 72.0 & 29.0 & 83.0 & $43.0^{* \dagger}$ \\
\hline CONV & 264.0 & 67.0 & 188 & 79.0 & 177.0 & 40.0 & 171.0 & 54.0 \\
\hline \multicolumn{9}{|c|}{ Carbohydrate (\%) } \\
\hline CRD & 51.0 & 14.0 & 30 & 19.0 & 21.0 & 10.0 & 29.0 & $14.0^{*}$ \\
\hline CONV & 51.0 & 9.0 & 49 & 7.0 & 47.0 & 9.0 & 48.0 & 7.0 \\
\hline \multicolumn{9}{|l|}{ Fat $(g)$} \\
\hline CRD & 89.0 & 38.0 & 71 & 46.0 & 78.0 & $32.0^{\dagger}$ & 58.0 & 30.0 \\
\hline CONV & 67.0 & 26.0 & 45 & 18.0 & 41.0 & 14.0 & 41.0 & $15.0^{*}$ \\
\hline \multicolumn{9}{|l|}{ Fat (\%) } \\
\hline CRD & 31.0 & 9.0 & 41 & 13.0 & 47.0 & 9.0 & 41.0 & $9.0^{*+}$ \\
\hline CONV & 28.0 & 8.0 & 27 & 9.0 & 25.0 & 4.0 & 25.0 & 4.0 \\
\hline \multicolumn{9}{|c|}{ Saturated fat (g) } \\
\hline CRD & 9.3 & 3.4 & 21.2 & 15.3 & 48.1 & 37.3 & 16.4 & $9.0^{\dagger}$ \\
\hline CONV & 6.6 & 4.0 & 9.6 & 5.9 & 8.4 & 4.5 & 9.0 & 4.7 \\
\hline \multicolumn{9}{|c|}{ Polyunsaturated fat (g) } \\
\hline CRD & 11.4 & 9.7 & 9.8 & 8.2 & 6.7 & 3.6 & 7,0 & 5.6 \\
\hline CONV & 9.7 & 5.5 & 6.5 & 4.6 & 6.7 & 4.4 & 11.3 & 5.3 \\
\hline \multicolumn{9}{|c|}{ Monounsaturated fat (g) } \\
\hline CRD & 28.1 & 11.8 & 25.2 & 19.5 & 27.8 & 15.5 & 18.0 & $11.0^{* \dagger}$ \\
\hline CONV & 22.3 & 14.0 & 10.6 & 6.4 & 10.2 & 4.0 & 11.3 & 5.3 \\
\hline \multicolumn{9}{|c|}{ Dietary fiber (g) } \\
\hline CRD & 14.5 & 4.9 & 6.4 & 3.6 & 5.4 & 5.0 & 6.2 & $3.7^{*+}$ \\
\hline CONV & 13.4 & 4.7 & 14.0 & 3.2 & 11.3 & 4.9 & 11.4 & 6.1 \\
\hline
\end{tabular}

Note: ${ }^{*} p<0.05$ compared to baseline values (Wilcoxon test); ${ }^{\dagger} p<0.05$ between CRD and CONV diet (Mann-Whitney diet). M: Mean; SD: Standard Deviation; CRD: Carbohydrate-Restrictive Diet; CONV: Conventional Diet. 
statistical significance was set at $p<0.05$. All statistical analyses were performed with commercially available software Statistical Package for the Social Sciences (SPSS Inc., Chicago, Illinois, United States), version 17.0

\section{RE S U L T S}

Subjects on the CRD significantly reduced their energy consumption by $48 \%(p=0.046)$, their carbohydrate consumption by $72 \%(p=0.028)$, and their fiber intake by $57 \%(p=0.028)$. Subjects on the conventional hypoenergetic diet significantly reduced their energy intake by $30 \%(p=0.028)$ and their total fat intake by $39 \%(p=0.028)$, but they did not significantly change their carbohydrate and fiber intakes (Table 1).
Reductions in body mass were similar between groups. The subjects in the CRD group lost $3.5 \pm 2.1 \%$ at four weeks $(p=0.002)$ and $5.4 \pm 3.5 \%$ at eight weeks $(p=0.001)$, while the conventional hypoenergetic diet group lost $2.4 \pm 2.1 \%(p=0.021)$ and $3.7 \pm 3.0 \%(p=0.015)$, respectively.

Individual analyses showed that half of the subjects in the carbohydrate-restrictive diets group $(6 / 12)$ and one third of (3/9) subjects in the conventional diet group lost more than $5 \%$ of their initial body mass. Changes in anthropometric variables are shown in Table 2.

Subjects in both groups increased their total strength as a result of resistance training. The carbohydrate-restrictive diets subjects increased their strength by $14 \%(p=0.005)$, and

Table 2. Changes in anthropometric characteristics of subjects on a Carbohydrate-Restrictive Diet or a Conventional Diet enrolled in an eight-week resistance training program. Rio de Janeiro (RJ), Brazil, 2008

\begin{tabular}{|c|c|c|c|c|c|c|}
\hline \multirow{2}{*}{ Variables } & \multicolumn{2}{|c|}{ Baseline } & \multicolumn{2}{|c|}{ Week 4} & \multicolumn{2}{|c|}{ Week 8} \\
\hline & M & SD & M & SD & $M$ & SD \\
\hline \multicolumn{7}{|c|}{ Body mass $(\mathrm{kg})$} \\
\hline CRD & 88.4 & 18.1 & 85.2 & $16.8^{*}$ & 83.4 & $16.2^{*}$ \\
\hline CONV & 80.4 & 20.3 & 78.3 & $18.8^{*}$ & 77.1 & $16.7^{\star}$ \\
\hline \multicolumn{7}{|c|}{ Body mass index $\left(\mathrm{kg} \cdot \mathrm{m}^{-2}\right)$} \\
\hline CRD & 30.7 & $3.9^{\dagger}$ & 29.6 & $3.4^{*}$ & 29.0 & $3.2^{*}$ \\
\hline CONV & 27.7 & 2.5 & 27.0 & $2.1^{*}$ & 26.7 & $1.8^{*}$ \\
\hline \multicolumn{7}{|c|}{ Fat free mass $(\mathrm{kg})$} \\
\hline CRD & 58.3 & 11.2 & 58.2 & 11.6 & 59.3 & 11.2 \\
\hline CONV & 58.6 & 17.0 & 58.6 & 16.8 & 58.6 & 16.9 \\
\hline \multicolumn{7}{|c|}{ Fat mass $(\mathrm{kg})$} \\
\hline CRD & 24.5 & 5.2 & 21.8 & $4.3^{*}$ & 19.5 & $5.0^{*}$ \\
\hline CONV & 21.9 & 5.1 & 19.7 & $4.3^{*}$ & 18.5 & $3.9^{*}$ \\
\hline \multicolumn{7}{|c|}{ Fat mass (\%) } \\
\hline CRD & 29.8 & 6.0 & 27.6 & $6.1^{*}$ & 25.1 & $6.9^{*}$ \\
\hline CONV & 27.7 & 4.9 & 25.8 & 5.6 & 24.8 & $6.0^{*}$ \\
\hline \multicolumn{7}{|c|}{ Waist girth $(\mathrm{cm})$} \\
\hline CRD & 90.5 & 14.0 & 87.9 & $13.3^{*}$ & 86.5 & $12.6^{*}$ \\
\hline CONV & 88.2 & 12.4 & 85.9 & $1.4^{*}$ & 84.8 & $10.9^{\star}$ \\
\hline \multicolumn{7}{|c|}{ Sum of 4 skinfolds $(\mathrm{mm})$} \\
\hline CRD & 118.6 & 25.9 & 106.9 & $20.9^{*}$ & 106.1 & 22.8 \\
\hline CONV & 100.7 & 18.1 & 92.8 & $23.3^{*}$ & 87.9 & $21.6^{*}$ \\
\hline
\end{tabular}

Note: ${ }^{*} p<0.025$ compared to baseline (Wilcoxon test); ${ }^{\dagger} p<0.05$ between CRD and CONV (Mann-Whitney test); Four skinfolds were triceps, abdominal, supra-ilium and anterior thigh.

M: Mean; SD: Standard Deviation; CRD: Carbohydrate-Restrictive Diet; CONV: Conventional Diet. 
the strength of the subjects in the conventional diet group increased by $21 \%(p=0.028)$.

Glucose, triacylglycerol, total cholesterol, HDL-C, and LDL-C did not change significantly within or between groups. A significant reduction $(12.8 \% ; p=0.037)$ was observed in the total cholesterol/HDL ratio in the CRD subjects (Table $3)$.

Table 3. Changes in blood variables of subjects on a carbohydrate-restrictive diet or a conventional diet enrolled in an eight-week resistance training program. Rio de Janeiro (RJ), Brazil, 2008.

\begin{tabular}{|c|c|c|c|c|}
\hline \multirow{2}{*}{ Variables } & \multicolumn{2}{|c|}{ Baseline } & \multicolumn{2}{|c|}{ Week 8} \\
\hline & M & SD & M & SD \\
\hline \multicolumn{5}{|c|}{ Glucose $\left(m m o / \cdot L^{-1}\right)$} \\
\hline CRD & 86.9 & 10.5 & 82.7 & 9.4 \\
\hline CONV & 84.9 & 6.9 & 88.1 & 9.0 \\
\hline \multicolumn{5}{|c|}{ Triacylglycerol $\left(\mathrm{mmo} / \mathrm{L}^{-1}\right)$} \\
\hline CRD & 116.5 & 52.5 & 83.4 & 27.6 \\
\hline CONV & 91.6 & 46.8 & 79.6 & 39.7 \\
\hline \multicolumn{5}{|c|}{ Total cholesterol $\left(\mathrm{mmol} \cdot \mathrm{L}^{-1}\right)$} \\
\hline CRD & 194.0 & 40.6 & 189.4 & 36.9 \\
\hline CONV & 191.3 & 47.8 & 188.1 & 51.6 \\
\hline \multicolumn{5}{|c|}{ HDL-cholesterol $\left(\mathrm{mmo} / \mathrm{L}^{-1}\right)$} \\
\hline CRD & 52.4 & 14.7 & 56.8 & 10.5 \\
\hline CONV & 53.3 & 11.6 & 52.3 & 12.3 \\
\hline \multicolumn{5}{|c|}{ TC/HDL-c ratio } \\
\hline CRD & 3.9 & 1.1 & 3.4 & $0.5^{*}$ \\
\hline CONV & 3.7 & 1.1 & 3.7 & 1.2 \\
\hline \multicolumn{5}{|c|}{ LDL-cholesterol $\left(\mathrm{mmol}^{\left.\circ-\mathrm{L}^{-1}\right)}\right.$} \\
\hline CRD & 118.7 & 29.8 & 115.9 & 29.4 \\
\hline CONV & 119.7 & 41.1 & 119.9 & 51.7 \\
\hline \multicolumn{5}{|c|}{ VLDL-cholesterol $\left(\mathrm{mmo}^{\circ} \mathrm{L}^{-1}\right)$} \\
\hline CRD & 23.3 & 10.5 & 16.9 & 5.8 \\
\hline CONV & 19.7 & 10.2 & 17.5 & 8.3 \\
\hline \multicolumn{5}{|c|}{ Urea $\left(m m o / \cdot L^{-1}\right)$} \\
\hline CRD & 26.6 & 6.9 & 29.8 & 7.9 \\
\hline CONV & 32.4 & 10.3 & 35.6 & 9.7 \\
\hline \multicolumn{5}{|c|}{ Creatinine $\left(\mathrm{mmo} \cdot \mathrm{L}^{-1}\right)$} \\
\hline CRD & 0.8 & 0.2 & 0.9 & 0.2 \\
\hline CONV & 1.0 & 0.1 & 1.0 & 0.1 \\
\hline \multicolumn{5}{|c|}{ Uric acid $\left(m m o / \cdot L^{-1}\right)$} \\
\hline CRD & 254.0 & 55.7 & 251.0 & 63.9 \\
\hline CONV & 316.9 & 109.1 & 296.6 & 85.7 \\
\hline \multicolumn{5}{|c|}{$A L T$ (units $\cdot L^{-1}$ ) } \\
\hline $\mathrm{DRC}$ & 26.1 & 14.0 & 19.0 & 8.1 \\
\hline CONV & 21.9 & 11.3 & 23.1 & 6.8 \\
\hline \multicolumn{5}{|c|}{$h s C R P\left(m g \cdot d L^{-1}\right)$} \\
\hline DRC & 1.16 & 1.36 & 1.49 & 1.50 \\
\hline CONV & 0.39 & 0.21 & 0.38 & 0.26 \\
\hline
\end{tabular}

Note: ${ }^{*} p<0.05$ between baseline and week 8 within CRD group (Wilcoxon test).

TC: Total Cholesterol; HDL: High Density Lipoprotein; LDL: Low Density Lipoprotein; VLDL: Very Low Density Lipoprotein; ALT: Alanine Aminotransferase; hsCRP: High Sensitivity C-reactive Protein; M: Mean; SD: Standard Deviation; CRD: Carbohydrate-Restrictive Diet; CONV: Conventional Diet. 
Changes in high sensitivity C-reactive protein, urea, creatinine, uric acid and ALT were not significant in either group (Table 3). Individual analyses showed that one subject in the CRD group had increased high sensitivity C-reactive protein levels, whereas another from the same group who had begun with high ALT levels reached normal values at the end of study.

Flow-mediated dilation was not significantly changed after eight weeks of intervention in either group (Figure 1).

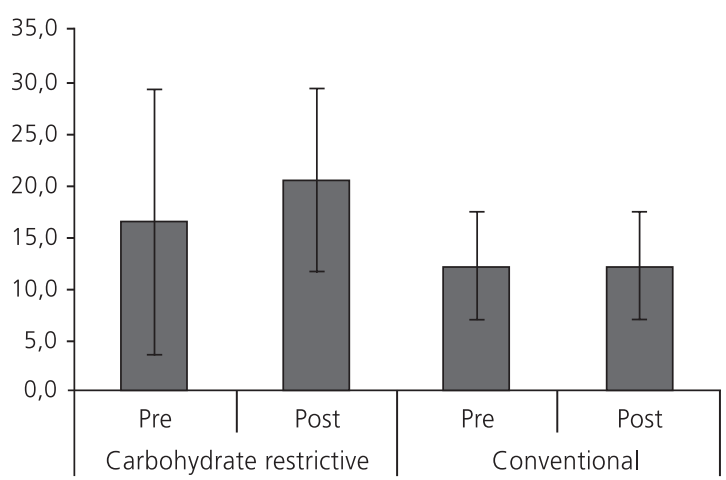

Figure 1. Changes in flow-mediated brachial artery dilation of subjects on carbohydrate restrictive diet $(n=7)$ and conventional diet $(n=7)$ associated to a resistance training program during eight weeks. Data are mean and standard deviation. Rio de Janeiro (RJ), Brazil, 2008.

Analyses of individual cases showed that 2/7 subjects in the CRD group and 3/7 in the conventional diet group had low baseline FMD values. At the end of intervention, one subject in each group had improved FMD values. Two subjects in the conventional hypoenergetic diet group with normal initial FMD values showed reductions to less than desirable values. None of participants in the CRD group reduced their initial values to below the desirable FMD value.

\section{DISCUSSION}

The main findings of the present study are that during an eight-week intervention program (resistance training and diet), neither a hypoenergetic CRD nor a conventional diet led to significant different changes in body and fat masses, maintenance of fat-free mass, FMD, or other metabolic variables.

Both groups significantly reduced their energy intake, although the dietary methods differed. The mean carbohydrate intake among the CRD group was $83 \pm 43 \mathrm{~g}$ at week 8 , and all subjects ingested amounts below the upper limit that characterizes a CRD ( $<150 \mathrm{~g}$ daily $)^{2}$. In the CRD group, the ingestion of carbohydrate was below the recommendations of $\mathrm{IOM}^{13}$, while protein and fat intakes were above the upper limits. In conventional hypoenergetic diet, the three macronutrients were ingested within the range recommended by $\mathrm{IOM}^{13}$. In CRD group, voluntary energy restriction might be due either to the moderate protein ingestion and/or to the low glycemic index inherent of this type of diet.

Paddon-Jones et al. ${ }^{19}$ reported that protocols involving moderate protein diets and resistance exercises may help maintain fat-free body mass due to their appetite-suppressant properties as well as the increased total energy expenditure caused by the thermic effect of protein. Ludwig ${ }^{20}$ showed that low glycemic index diets result in higher satiety, decreased appetite and voluntary energy ingestion.

The lack of a significant difference in loss of body mass between the CRD group and the conventional diet group is in agreement with

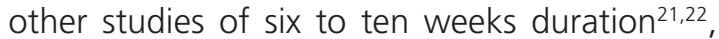
although it does not agree with a previous systematic review designed to investigate the effects of CRD on body mass loss ${ }^{3}$.

The magnitude of body mass loss in the current study was lower than that reported in the published studies, which found decreases of about $7 \%$ during the intervention period, however, the current study has combined progressive resistance training with CRD and conventional diets. Johnstone et al. ${ }^{23}$ reported that four weeks of non-ketogenic CRD (approximately 35\% of total energy from carbohydrate) led to a significantly lower body mass loss (-4.4 kg versus $-6.3 \mathrm{~kg}$ ) than 
an isoenergetic ketogenic CRD (approximately 4\% of total energy from carbohydrate), suggesting that carbohydrate restriction may maximize losses in body mass. Previous studies comparing the effects of CRD and conventional diets without resistance training reported significant decreases in fat-free mass in both interventions (from -1.4 to $-3.2 \mathrm{~kg}$, representing up to $32 \%$ of total body mass reduction) 2,6,10,24,25. However, despite the short duration of the present intervention, CRD associated to resistance training seemed to prevent fat-free mass loss.

A relevant point to be discussed is the need for gluconeogenesis from amino acid carbon skeletons during a low-carbohydrate diet. This gluconeogenic role of dietary proteins has been hypothesized as being involved in their greater satiating power when compared with other macronutrients. In addition, protein exhibits a high thermic effect, as a result of the energy cost of urea synthesis and gluconeogenesis from amino acids. Both effects - satiating power and thermogenesis - are referred to help during body mass loss. It is expected that the decreased supply of carbohydrate would lead to low blood levels of insulin and reduce the lean body mass preservation. However, in the present study, the association between CRD and resistance training could possibly translate to a healthier body composition status, since even low quantities of amino acids are useful to promote muscle protein synthesis when stimulated by the resistance training ${ }^{26}$.

It should be pointed out, however, that subjects in CRD ingested hypoenergetic diets with protein content of $29-32 \%$, what is only apparently high in protein compared to a conventional diet group with a protein level of $22-26 \%$, although the total grams of protein relative to body mass did not differ between the two types of diet.

Waist girth significantly decreased in both groups after the intervention, but no significant differences were observed between CRD and conventional diets, similar to other reports ${ }^{7,8}$, and discrepant from Volek et al. ${ }^{24}$.
Other than the total cholesterol/HDL ratio in the CRD group, no significant changes were observed either within or between groups in the present study. These results were similar to other reporting data from four weeks of intervention ${ }^{23}$. However, it is typically observed that a CRD promotes higher reductions in triacylglycerol and increases in HDL-c levels compared to conventional diets $^{22,25}$. Wood et al. ${ }^{27}$ also reported that improvements in HDL-c were better in the CRD group versus the low-fat diet group after 12 weeks of hypoenergetic diets with progressive resistance training.

According to a cohort study carried out in more than 8,000 subjects $^{24}$, the total cholesterol/ $\mathrm{HDL}$ ratio is a superior measure of risk for coronary heart disease compared to either total cholesterol or LDL-c cholesterol levels. Therefore, the greater reduction in total cholesterol/HDL-c ratio noted in the CRD group in the present study might indicate some additional benefit of carbohydrate restriction beyond calorie restriction.

Subjects in the present study did not present significant reductions in high sensitivity C-reactive protein levels either within or between groups, although significant reductions were observed in body mass. On the contrary, Seshadri et al. ${ }^{10}$ observed that reductions in high sensitivity C-reactive protein were directly associated with body mass loss. Results similar to the present study were reported by Phillips et al. ${ }^{5}$ and Keogh et al. ${ }^{7}$, who found that significant body mass reductions were independent of modifications in high sensitivity C-reactive protein levels in subjects submitted to six to twelve weeks of a CRD or conventional diet without exercise.

Pre- to post-intervention changes in FMD were also not statistically significant, as previously reported after six weeks to two years of eight weeks of $\mathrm{CRD}^{6-8,28,29}$. Conversely, Phillips et al. ${ }^{5}$ observed significant reductions in FMD in CRD dieters $(-1.4 \pm 0.6 \%)$ and significant increases in that of conventional dieters $(+1.9 \pm 0.8 \%)$ along with an approximately $5 \mathrm{~kg}$ body mass reduction in both groups after six weeks of intervention. 
The available evidence on the effects of resistance training on endothelial function is scarce, but it appears that changes are manifested in subjects with some endothelial dysfunction, as observed in young prehypertensive subjects ${ }^{30}$. Among subjects with abnormal FMD, similar to one subject in the CRD and one in the conventional diet group, values increased to above the cut-off point. The lack of significant effects of the intervention on FMD might be explained by the small changes in body mass, blood lipids and high sensitivity C-reactive protein levels. It could be speculated that greater changes in those variables would be necessary to provoke significant alterations of FMD.

No significant changes were observed in renal or liver functions as assessed by urea, creatinine, uric acid and ALT levels. These results were probably due to the maintenance of total protein intake. Although it is well accepted that a high-protein diet may be detrimental to individuals with existing kidney dysfunction, there is little evidence that high protein intake is dangerous for healthy individuals ${ }^{31}$. Based on the current evidence, CRD interventions do not seem to impair organic functions in obese subjects, even over a two-year period ${ }^{32}$. But further research is needed to confirm their safety over a longer term and with broader study populations.

A potential limitation of the present study is that subjects could choose their own diet intervention, although this approach probably strengthened the ecological validity of the study. It is recognized that dieters tend to drop out of restrictive dieting programs if they find it too difficult to adhere to some of the food choices either because they are not familiar with them or because they dislike the choices.

In conclusion, the present study showed similar effects of hypoenergetic diets and resistance training on body mass loss and health markers in overweight and obese individuals, regardless of their carbohydrate intake. Therefore, a CRD may be an alternative intervention for treating individuals in this population provided there is no specific contraindication. Further research is needed in other groups and for longer periods to determine the effects of CRD associated to resistance training in supporting weight maintenance or weight regain.

\section{CONTRIBUTORS}

CM MEIRELLES and PSC GOMES jointly developed the study's concept and design, collected and analyzed the data, and wrote the manuscript.

\section{REFERE N CES}

1. American Dietetic Association. Position stand on weight management. J Am Diet Assoc. 2009; 109(2):330-6. http://dx.doi.org/10.1016/j.jada. 2008.11.041

2. Westman EC, Feinman RD, Mavropoulos JC, Vernon MC, Volek JS, Wortman JA, et al. Low-carbohydrate nutrition and metabolism. Am J Clin Nutr. 2007; 86(2):276-84.

3. Hession M, Rolland C, Kulkarni U, Wise A, Broom J. Systematic review of randomized controlled trials of low-carbohydrate vs low-fat/low-calorie diets in the management of obesity and its comorbidities. Obes Rev. 2009; 10(1):36-50. http://dx.doi.org/ 10.1111/j.1467-789X.2008.00518.x

4. Patel AR, Kuvin JT, Sliney KA, Rand WM, Chiang $J C$, Udelson JE, et al. Gender-based differences in brachial artery flow-mediated vasodilation as an indicator of significant coronary artery disease. Am J Cardiol. 2005; 96(9):1223-6. http://dx.doi.org/ 10.1016/j.amjcard.2005.06.060

5. Phillips $S A$, Jurva JW, Syed $A Q$, Syed $A Q$, Kulinski $J P$, Pleuss J, et al. Benefit of low-fat over low-carbohydrate diet on endothelial health in obesity. Hypertension. 2008; 51(2):376-82. http://dx. doi. org/10.1161/HYPERTENSIONAHA.107.101824

6. Buscemi S, Verga S, Tranchina MR, Cottone S, Cerasola G. Effects of hypocaloric very-low-carbohydrate diet vs Mediterranean diet on endothelial function in obese women. Eur J Clin Invest. 2009; 39(5):339-47. http://dx.doi.org/10.1111/j.1365-23 62.2009.02091.x

7. Keogh JB, Brinkworth GD, Clifton PM. Effects of weight loss on a low-carbohydrate diet on flow-mediated dilatation, adhesion molecules and adiponectin. Br J Nutr. 2007; 98(4):852-9. http:// dx.doi.org/10.1017/S0007114507747815

8. Keogh JB, Brinkworth GD, Noakes M, Belobrajdic DP, Buckley JD, Clifton PM. Effects of weight loss 
from a very-low-carbohydrate diet on endothelial function and markers of cardiovascular disease risk in subjects with abdominal obesity. Am J Clin Nutr. 2008; 87(3):567-76.

9. Ridker PM, Stampfer MJ, Rifai N. Novel risk factors for systemic atherosclerosis a comparison of c-reactive protein, fibrinogen, homocysteine, lipoprotein(a), and standard cholesterol screening as predictors of peripheral arterial disease. Jama. 2001; 285(19):2481-5. http://dx.doi.org/10.1001/jama. 285.19.2481

10. Seshadri $P$, Iqbal N, Stern L, Williams M, Chicano $\mathrm{KL}$, Daily DA. A randomized study comparing the effects of a low-carbohydrate diet and a conventional diet on lipoprotein subfractions and C-reactive protein levels in patients with severe obesity. Am J Med. 2004; 117(6):398-405. http:// dx.doi.org/10.1016/j.amjmed.2004.04.009

11. American College of Sports Medicine. Position stand: Appropriate intervention strategies for weight loss and prevention of weight regain for adults. Med Sci Sports Exerc. 2009; 41(2):459-71. http://dx.doi.org/10.1249/MSS.0b013e3181 949333

12. World Health Organization. Human energy requirements. Report of a Joint FAOMHO/UNU Expert consultation. Rome: WHO; 2004.

13. Institute of Medicine, Food and Nutrition Board. Dietary Reference Intakes: Macronutrients. Washington (DC); 2005. [cited 2010 July 24]. Available from: http://www.nap.edu

14. Jackson AS, Pollock ML. Generalized equations for predicting body density of men. Br J Nutr. 1978; 40(3):497-504. http://dx.doi.org/10.1079/BJN197 80152

15. Jackson AS, Pollock ML, Ward A. Generalized equations for predicting body density of women. Med Sci Sports Exerc. 1980; 12(3):175-81. http:// dx.doi.org/10.1249/00005768-198023000-00009

16. Siri WE. Body composition from fluid spaces and density. In Brozek J, Henschel A, editors. Technics for measuring body composition. Washington (DC): National Academy of Sciences; 1961. p.223-4.

17. Friedewald WT, Levy RI, Fredrickson DS. Estimation of the concentration of low-density lipoprotein cholesterol in plasma, without use of the preparative ultracentrifuge. Clin Chem. 1972; 18(6):499-502.

18. Meirelles CM, Leite SP, Montenegro CAB, Gomes PSC. Reliability of brachial artery flow-mediated dilatation measurement using ultrasound. Arq Bras Cardiol. 2007; 89(3):160-7. http://dx.doi.org/ 10.1590/S0066-782X2007001500006
19. Paddon-Jones D, Sheffield-Moore M, Zhang X, Volpi E, Wolf SE, Aarsland A, et al. Amino acid ingestion improves muscle protein synthesis in the young and elderly. Am J Physiol Endocrinol Metab. 2004; 286(3):E321-8. http://dx.doi.org/10.1152/ ajpendo.00368.2003

20. Ludwig DS. Dietary glycemic index and obesity. J Nutr. 2000; 130(2S Suppl):280S-3S.

21. Sharman MJ, Gómez AL, Kraemer WJ, Volek JS. Very low-carbohydrate and low-fat diets affect fasting lipids and postprandial lipemia differently in overweight men. J Nutr. 2004; 134(4):880-5.

22. Noakes M, Foster PR, Keogh JB, James AP, Mamo JC, Clifton PM. Comparison of isocaloric very carbohydrate restrictive/high saturated fat and high carbohydrate/low saturated fat diets on body composition and cardiovascular risk. Nutr Metab. 2006: 3:7. http://dx.doi.org/10.1186/1743-707 5-3-7

23. Johnstone AM, Horgan GW, Murison SD, Bremner DM, Lobley GE. Effects of a high-protein ketogenic diet on hunger, appetite, and weight loss in obese men feeding ad libitum. Am J Clin Nutr. 2008; 87(1):44-55.

24. Volek JS, Sharman MJ, Gómez AL, Judelson DA, Rubin MR, Watson G, et al. Comparison of energyrestricted very low-carbohydrate and low-fat diets on weight loss and body composition in overweight men and women. Nutr Metab. 2004; 1:13. http:// dx.doi.org/10.1186/1743-7075-1-13

25. Bazzano LA, Hu T, Reynolds K, Yao L, Bunol C, Liu $Y$, et al. Effects of low-carbohydrate and low-fat diets: A randomized trial. Ann Intern Med. 2014; 161(5):309-18. http://dx.doi.org/10.7326/M14-0 180

26. Pesta D, Samuel V. A high-protein diet for reducing body fat: Mechanisms and possible caveats. Nutr Metab. 2014; 11:53. http://dx.doi.org/10.1186/17 43-7075-11-53

27. Wood RJ, Gregory SM, Sawyer J, Milch CM, Matthews TD, Headley SAE. Preservation of fat-free mass after two distinct weight loss diets with and without progressive resistance exercise. Metab Syndr Relat Disord. 2012; 10(3):167-74. http://dx. doi.org/10.1089/met.2011.0104

28. Volek JS, Ballard KD, Silvestre R, Judelson DA, Quann EE, Forsythe CE, et al. Effects of dietary carbohydrate restriction vs low-fat diet on flow-mediated dilation. Metab Clin Exp. 2009; 58(12):1769-77. doi: 10.1016/j.metabol.2009.06. 005

29. Mohler ER $3^{\text {rd }}$, Sibley AA, Stein R, Davila-Roman V, Wyatt $\mathrm{H}$, Badellino $\mathrm{K}$, et al. Endothelial function 
and weight loss: Comparison of low carbohydrate and low-fat diets. Obesity. 2013; 21(3):504-9. http:// dx.doi.org/10.1002/oby.20055

30. Beck DT, Martin JS, Casey DP, Braith RW. Exercise training improves endothelial function in resistance arteries of young prehypertensives. J Hum Hypertens. 2014; 28(5):303-9. http://dx.doi.org/ 10.1038/jhh.2013.109

31. Cuenca-Sánchez $M$, Naves-Carrillo D, OrenesPiñero E. Controversies surrounding high-protein diet intake: Satiating effect and kidney and bone health. Adv Nutr. 2015; 15(6):260-6. http://dx.doi. org/10.3945/an.114.007716

32. Tirosh A, Golan R, Harman-Boehm I, Henkin Y, Schwarzfuchs D, Rudich $A$, et al. Renal function following three distinct weight loss dietary strategies during 2 years of a randomized controlled trial. Diabetes Care. 2013; 36(8):2225-32. http:// dx.doi.org/10.2337/dc12-1846

Received: September 17, 2015

Final version: March 7, 2016

Approved: May 2, 2016 